\title{
School Types, Facilities and Academic Performance of Students in Senior Secondary Schools in Ondo State, Nigeria
}

\author{
Alimi, Olatunji Sabitu \\ Adekunle Ajasin University, Akungba-Akoko, Ondo State, Nigeria \\ Tel: 234-806-113-7511Ｅ-mail: alimiolatunji@yahoo.com \\ Ehinola, Gabriel Babatunde \\ Adekunle Ajasin University, Akungba-Akoko, Ondo State, Nigeria \\ Tel: 234-805-922-5814Ｅ-mail: gabrielehinola@yahoo.com \\ Alabi, Festus Oluwole \\ Adekunle Ajasin University, Akungba-Akoko, Ondo state, Nigeria \\ Tel: 234-803-364-1487Ｅ-mail: olualabi10@yahoo.com
}

Received: December 27, 2011

Accepted: December 29, 2011 Published: Apirl 18, 2012

doi:10.5539/ies.v5n3p44

URL: http://dx.doi.org/10.5539/ies.v5n3p44

\begin{abstract}
The study investigated the influence of school types and facilities on students' academic performance in Ondo State. It was designed to find out whether facilities and students' academic performance are related in private and public secondary schools respectively. Descriptive survey design was used. Proportionate random sampling technique was used to select 50 schools in Ondo state. Two set of research instruments named School Facility Descriptive and Students Academic Performance Questionnaire (SFDAPQ) for principals; and School Facility Descriptive Questionnaire (SFDQ) for the teachers were used for the study. T- test was used to analyze the data. All hypotheses were tested at a significant level of 0.05 . The study revealed a significant difference in facilities available in public and private schools in Ondo State. It however revealed no significant difference in academic performance of students in the two types of secondary schools. Suggestions for the procurement of more facilities in public secondary schools were made in order to enhance students' academic performance.
\end{abstract}

Keywords: Physical facilities, School types, Students’ performance, Social wastage, Measure of effectiveness

\section{Introduction}

Schools are established for the purpose of teaching and learning. It is also more important that the teachers and learners are properly accommodated to facilitate the teaching and learning that go on there. This is the essence of the school plant and facilities (Alimi 2004). Therefore school facilities are the space interpretation and physical expression of the school curriculum. In Nigeria at large and in Ondo State in particular, secondary schools, irrespective of ownership are expected to function in compliance with the achievement of the national education objectives. To this end, students are expected to perform brilliantly in the final examination as this determines the quality of output of secondary schools. This is one of the parameters used to measure the effectiveness of a school system. The better the performance of the students, the more effective the system is assumed to be (Philias \& Wanjobi 2011).In another related study, Cynthia \& Megan (2008) confirmed a strong and positive relationship between quality of school facilities and student achievement in English and Mathematics. In Nigeria, it is the general opinion of people that private schools are better in terms of the availability of human and physical facilities and consequently students' performance than public schools. This situation has made many parents to enroll their children in private secondary schools. Experience has also shown that most students who secured admission into tertiary institution such as Colleges of Education, Polytechnics and Universities are from private secondary schools.

The rate of poor academic performance of student in Nigeria had resulted to economic and social wastage and this have become a great concern to all stakeholders in education. For instance, in 2008, 25.94\% of the students had credits pass in English language and Mathematics. Also in year 2009, it was another year of poor result across all 
states of the federation. According to Okpala (2010) at the rational level, the percentage of candidates that had credit in English language between years 2005-2009 in West African Examinations Council (WAEC) are as follows: $27.53 \%$ in year $2005,15.56 \%$ in 2006, 22.54\% in 2007, $13.78 \%$ in 2008 and $24.94 \%$ in 2009 . He also stated that candidates who obtained credit passes in five subjects and above including English language and Mathematics between 2005 and 2009 are as follows: 8.53\% in year 2005, 13.32\% in 2006, 27.74\% in 2007, 10.53\% in 2008 and $1.80 \%$ in 2009.

The break-down of 2009 results in West African Senior School Certificate Examination (WASSCE) and National Examination Council (NECO) indicated a mass failure across the 36 states of the federation. From the analysis in 2009, it was recorded that in Ondo State which is the focus of this study less than $2 \%$ of the candidates who sat for the examination made five credits and above in NECO and WASSCE while $0.95 \%$ of the candidate made credit passes in English Language and Mathematics.

In August 2010, WAEC gave the outcome of the May/June 2010 exercise as achieving a 75 percent failure in English Language and Mathematics sitting alone! That report further showed that only 24.95 percent of the candidates who sat for the examinations, made five credits, including English Language and Mathematics, representing 337,071 of the 1,278,843 candidates whose results were released by the examination body. The WAEC Nov. /Dec. 2010 WASSC examination result in English and Mathematics, two subjects widely believed to be the pivot of the major fields of sciences and arts, was also nothing to write home about (Adeiza 2011). The failure was not just intense; it was truly hopeless in the sense of the situation in the post-primary training environment. In this case and as earlier declared on December 23, 2010 by the examinations body, only 20.04 per cent or 62,295 candidates obtained credit pass in English, Mathematics and other three subjects in the Nov. /Dec. 2010 examinations. This is a pointer to the fact that all is not well with the students' attainment in the cognitive domain.

Apart from the general poor performance referred to above, there appeared to be difference in performance from one school to the other. It may be argued that such variation in performance is unavoidable. Although, the incidence of poor performance appears to be more common in public secondary schools, private schools are not free from the declining trend.

The consequence of mass failure in public examination is the inability of learners to proceed to higher educational institution. As a result of this poor performance, stakeholders in education are curious to know the causal factors associated with the problem. Causes of the poor academic performance could include ownership of the school and inadequate facilities. Facilities are of everything used directly or indirectly for the benefit of education. Facilities could also be explained as the entire school plant such as blocks of classrooms, staffrooms, laboratories, workshops, libraries, laboratory equipment, consumables, audio-visual aids, electricity, water, chairs, tables, stationeries, playground, storage spaces and others which school has. It has always been realized that facilities are very important in the development and improvement of education in Nigeria. A school without facilities, either private or public, may not be able to achieve the stated goals and objectives of the system. When facilities are available and skillfully utilized, they influence learning and making it more meaningful. Facilities in education are very vital because they aid teaching and learning.

Bandele (2003) noted that the importance of physical facilities cannot be relegated. Facilities like modern laboratories, libraries and classrooms are to be put in place in all our schools. Adesola (2005) found out that the level of available resources is indeed a plus to the teachers and goes to show the level of ingenuity and commitment of the teachers toward effective delivery of lesson. There is the need for renovation of old buildings, chairs, desks, cabinets and acquisition of modern classrooms as earlier recommended by Alimi (2007). Akinfolarin (2008) identified facilities as a major factor contributing to academic performance in the schools system. These include classroom furniture, recreational equipment among others. Different studies conducted by Ayodele (2000) and Vandiver (2011), showed that a positive relationship exists between availability of facilities and student academic performances.

Research findings on the influences of facilities in private and public secondary schools on students' academic performance are controversial. Keeves (1978) found out that the type of school, classified as public or private did not make any difference on students' academic performance. However, Ajayi (2006), found out that school type make a difference in student academic performance. In addition, Philias \& Wanjobi (2011) reiterated that the type of schools, (single sex or mixed, private or public) has effect on the academic performance of students in Mathematics. Therefore, this study wants to find out whether a relationship exists in types of school, facilities and academic performance.

\subsection{Purpose of the Study}

The purpose of the study is to find out the influence of school types (based on ownership) on academic performance of senior secondary school students in Ondo State. The study will also examine whether public and private schools 
differ in term of facilities availability.

\subsection{Statement of the Problem}

Parents and other stakeholders in education have condemned the high rate of poor academic performance of students in external examinations: WAEC and NECO. This poor performance is not limited to public school alone, private school were also involved. Reasons range from poor teaching personnel and non-availability of school facilities. Therefore, the problem to which attention will be directed in this study is to what extent do school types (private and public) and facilities influence academic performance of students in senior secondary schools in Ondo State. On the basis of the background and statement of the problem two hypotheses were generated for the study.

\subsection{Hypotheses}

1) There is no significant difference in school facilities between public and private secondary schools in Ondo State.

2) There is no significant difference in the academic performance of students between private and public secondary schools in Ondo State.

\section{Methodology}

The survey type design of the descriptive research was used. The researcher collected information that describes the facilities situation in private and public schools. The population consists of all senior secondary school teachers and principal in public and private secondary schools in Ondo State.

Fifty senior secondary schools were purposively sampled to include 36 public senior secondary schools and 14 private senior secondary schools. These schools participated in the study.

\subsection{Instrument}

Two instruments named School Facility Descriptive and Student Academic Performance Questionnaire (SFDSAPQ) for principal only; and Schools Facility Descriptive Questionnaire (SFDQ) for teachers were used for the study. The first instrument sought information on type of schools, background and physical facilities of the school and the results of students in the Senior School Certificate Examination in each of English Language, Mathematics and Biology. The second instrument sought information from teachers who taught the three core subjects earlier listed.

\section{Results}

Hypotheses 1 and 2 were tested by using T-test.

Hypothesis 1: There is no significant difference in facilities between public and private senior secondary schools in Ondo State.

As shown in table1 the mean of facilities availability in private school (68.29) was higher than that of public schools (52.42). The table shows further that the $\mathrm{t}$-cal (5.764) is greater than the t-table (2.021) at $\mathrm{P}<.05$ level of significance. Therefore, the null hypothesis is rejected. This shows that there was a significant difference in the facilities available in public and private schools

Hypothesis 2: There is no significant difference in the academic performance of students between private and public secondary school in Ondo State.

The result in table 2 shows that the mean performance of students in private schools (17.42) is slightly higher than their counterparts in the public schools (17.20). However, the t-cal (0.042) is less than t-table (2.021) at $\mathrm{P}<0.05$ level. Therefore the null hypothesis is accepted. Meaning that, there was no significant difference in the academic performance of students in public and private senior secondary schools in Ondo State

\section{Discussion}

The study revealed that there is a significant difference in the facilities available between public and private senior secondary schools, with (t-cal 5.764 and t-table 2.021). Private schools appear to have a higher index of facilities than public schools with 68.29 and 52.42 for the private and public schools respectively. If facilities have been found to be related to academic performance, as reiterated by Ayodele (2000), Cynthia \& Megan (2008), and Philias \& Wanjobi (2011), one expects a better performance in private schools than in public schools. In any case, private school proprietors appear to inject more funds on facilities than public schools.

In hypothesis two, the study revealed that there is no significant difference in the academic performance of students in public and private senior secondary schools in Ondo State. This study disagreed with the work of Philias \& Wanjobi (2011) who reiterated that the type of schools, (single sex or mixed, private or public) has effect on the academic performance of students in Mathematics. This finding is however in tandem with Keeves (1978) who 
subscribed that the type of school, classified as public or private did not make any difference in the determination of students' academic performance. As shown in this study, it appears that whether a pupil attended a private or a public school does not matter. What have been found to be related to students' performance are the facilities available in the course of programme implementation. It could be that most of the private schools are now recruiting professional teachers to offset lapses so as to compete with public schools. It could also be that most of the private secondary schools use comparable salary structure with public schools. Some private schools have been found to be paying even higher salaries than public schools. This could be an additional motivating factor for comparable performance in the two types of schools.

However, this finding negates Olutola (1989) who used a checklist of facilities in Kwara State and government policy on private schools to determine the relationship between educational facilities and school academic performance. The study showed that private schools with high standard of prescribed educational facilities did perform better in WASC examination than public schools.

The present findings possibly could help to dispel the rumor that private schools are just money-making schools without good academic standards. Indeed in this study, the mean of student performance in private schools is a little better than in public school (private 17.42, public 17.2). This difference is however not statistically significant. .

\section{Conclusion and Recommendations}

The findings of this study revealed significant difference in the facilities availability between private and public secondary schools. Government should therefore inject more funds into the system for the procurement of teaching and learning facilities. This responsibility lies on the educational planners and administrators in the Ministry of Education. Also, corporate organizations and individuals should be encouraged by the government to donate generously in cash and kind for the provision of educational facilities especially the needed one for the core subjects in public schools.

Apart from school and public libraries, education resource centres should be established by government such as teacher centres and audio visual centres. Teachers' centres could serve as place where teachers could work together in groups to generate ideas that would make them more competent in the profession. Also, teachers should be made to use instructional facilities while teaching and where they are not available improvisation should be adopted.

It could be concluded that government did not inject facilities into public schools when compared with facilities available in private schools. Therefore, government should give priority to public schools in the provision of facilities.

\section{References}

Adeiza, A. (2011). Avoiding a Repeat of Mass Failure in Subsequent WAEC /NECO Examinations. [Online] Available: http:www.peoplesdaily-online.com/news/education/2348. (Sept. 24, 2011)

Adesola, A. A. (2005). Resource Provision and Utilization, Mathematics Ability and learning Environment as prediction of learning Outcome in Undergraduate Practical Geography. Unpublished Ph.D Thesis, University of Ibadan, Ibadan.

Ajayi, A. (2006). The Influence of School Type and Location on Resource Availability and Pupils Learning Outcome in Primary Schools in Ekiti State, Nigeria. Educational Thought, 5(1): 170-176.

Akinfolarin, C. A. (2008). Resource utilization in Vocational and Technical Education in Colleges of Education in South-West Nigeria.Unpublished Ph.D Thesis.University of Ado-Ekiti, Ado-Ekiti.

Alimi, O. S. (2004). Appraisal of the Adequacy of Available School Plant for Primary Education In Ayedaade Local Government Area of Osun State. Educational Thought, 4(1) 64-69

Alimi, O. S. (2007). Physical Plant Maintenance Practices in the Public Secondary Schools in Akoko Zonal Education Area of Ondo State. Ife Journal of Educational Studies, 13(1):73-78

Ayodele, J. B. (2000). School Size, Class Size and Teacher's Quality as Correlation of Internal Efficiency in Primary School in Ondo State, Nigeria; Unpublished PhD Thesis, University of Ibadan, Ibadan.

Bandele, S. O. (2003). The Universal Basic Education in Perspective, Need for Formative Evaluation. Nigeria Journal of Educational Research and Evaluation, 1(4), 54-56.

Cynthia, U., \& Megan, T. (2008). The Walls Speak: the interplay of quality facilities, school climate, and student achievement. Journal of Educational Administration, 46 (1), 55-73. http://dx.doi.org/10.1108/09578230810849817

Keeves, J. P. (1978). Approaches to the goal of Educational Equality in renewal of Australian Schools; In Cruz, J. V. $D$ \& Sheehan, P. J (Eds) A Changing Perspective in Educational Planning, Malbourne; ACER 92-107 
Okpala, P. (2010). Season of Mass Failure. The Nation, April 15, 2010.

Philias, O. Y., \& Wanjobi, W. C. (2011). Performance Determinants of Kenya Certificate of Secondary Education (KCSE) in Mathematics of Secondary Schools in Nyamaiya Division, Kenya. Asian Social Science, 7 (2), 107-112

Vandiver, B. (2011). The Impact of School facilities on the Learning Environment. Unpublished Doctoral Dissertation, Capella University.

Table 1. t-Test Summary on Facilities in Public and Approved Private Senior Secondary School in Ondo State

\begin{tabular}{|l|l|l|l|l|l|ll|}
\hline Source & N & Mean & SD & Df & t cal & t cal & S \\
\hline Private Sec. Schools & 14 & 68.29 & 8.94 & & & & \\
Public Sec. Schools & 36 & 52.42 & 8.67 & & & & \\
\hline
\end{tabular}

* Significant at 0.05 level (2-tailed)

Table 2. t-Test Summary on Students' Academic Performance in Public and Private Senior Secondary School in Ondo State.

\begin{tabular}{|l|l|l|l|l|l|ll|}
\hline \multicolumn{1}{|c|}{ Source } & N & Mean & SD & Df & t cal & t cal & S \\
\hline Private Sec. Schools & 14 & 17.42 & 13.06 & & & & \\
Public Sec. Schools & 36 & 17.20 & 18.23 & & & & \\
\hline
\end{tabular}

Not Significant at 0.05 level (2-tailed) 